DOI: $10.19195 / 0137-1150.170 .13$

Data przesłania artykułu: 3.09 .2018

Data akceptacji artykułu: 29.12.2018

\title{
AGNIESZKA KOLODZIEJ
}

Uniwersytet Wrocławski, Polska

\section{Onomastyczny spacer ścieżkami belgradzkiego ogrodu zoologicznego}

Ogrody zoologiczne, uważane za archetypy dawnych zwierzyńców, ptaszarni czy też wiwariów ${ }^{1}$, należą do jednych z najciekawszych atrakcji znajdujących się na terenie aglomeracji miejskich. Stanowią one integralną część infrastruktury turystyczno-wypoczynkowej przede wszystkim dużych miast, pełniąc przy tym funkcję nie tylko czysto rozrywkową, lecz także edukacyjną ${ }^{2}$.

Szczególnie ciekawym i wdzięcznym tematem do analiz dla onomasty są zoonimy, czyli nazwy własne zwierząt. Warto dodać, że imiennictwo zwierząt żyjących w ogrodach zoologicznych, chociaż w mniejszym stopniu niż na przykład nazewnictwo ruro- bądź urbozoonimiczne, stało się przedmiotem zainteresowania badaczy. Tematyce tej swoje prace poświęcili lingwiści polscy — Sławomira Tomaszewska $^{3}$, Jerzy Głowacki ${ }^{4}$, Ewa Jakus-Borkowa ${ }^{5}$, Agnieszka Kołodziej ${ }^{6}$

1 A. Habel, S. Mroczkowski, Cele i zadania ogrodów zoologicznych, „Journal of Education, Health and Sport" 5, 2015, z. 8, s. 522.

2 Zgodnie z brzmieniem ustawy o ochronie przyrody ogród zoologiczny należy definiować jako ,urządzony i zagospodarowany teren wraz z infrastrukturą techniczną i budynkami funkcjonalnie z nim związanymi, gdzie zwierzęta gatunków dziko występujących są hodowane i utrzymywane w celu ochrony ex situ, prowadzenia badań naukowych i edukacji oraz w celu ich publicznej ekspozycji nie mniej niż 7 dni w roku". Ustawa z dnia 16 kwietnia 2004 roku o ochronie przyrody, s. 6057, http://prawo.sejm.gov.pl/isap.nsf/download.xsp/WDU20040920880/O/D20040880.pdf [dostęp: 15.07.2018].

3 S. Tomaszewska, Nazwy własne zwierząt łódzkiego Ogrodu Zoologicznego, „Rozprawy Komisji Językowej ŁTN” 25, 1979, s. 109-122.

4 J. Głowacki, Imiona własne zwierząt w Ogrodzie Fauny Polskiej w Bydgoszczy, „Język Polski" 77, 1992, s. 151-153.

5 E. Jakus-Borkowa, Nazwy własne zwierzą ogrodów zoologicznych w Opolu i we Wrocławiu, [w:] Systemy zoonimiczne w językach stowiańskich, red. S. Warchoł, Lublin 1996, s. 199-215.

6 A. Kołodziej, Nazewnictwo zwierząt ogrodów zoologicznych, [w:] Propria a apelativa aktuálni otázky. Proper Names and Common Nouns - Current Issues, red. L. Janovec, Praha 2019, s. 57-66. 
oraz niemieccy — Petra Ewald i Christian Klager ${ }^{7}$. Innym zagadnieniem rozpatrywanym przez językoznawców, łączącym dwie płaszczyzny językowe - proprialną $\mathrm{i}$ apelatywną — są nazwiska $\mathrm{z}$ komponentem w postaci nazw pospolitych zwierząt, komponentem animalistycznym/zoonimicznym ${ }^{8}$. Zwraca się również uwagę na przezwiska motywowane nazwami gatunkowymi zwierząt9.

Na podstawie przeprowadzonych przez autorkę artykułu badań okazało się, że ogród zoologiczny nie tylko może dostarczyć cennego materiału umożliwiającego przeprowadzenie eksploracji w obrębie bionimicznego planu języka, prezentowanego przez wspomniane zoonimy oraz antroponimiczne kategorie nazwiska i przezwiska, ale można w nim odnaleźć także elementy należące do planu geonimicznego.

Przedmiotem niniejszej rozprawy będą więc nazwy miejskie, stanowiące jedną z kategorii geonimów, dalej specyfikując — toponimów, określane również jako urbanonimy ${ }^{10}$, zaświadczone na terenie ogrodu zoologicznego w Belgradzie. Obecność nazw o charakterze toponimicznym na terenie zoo jest zjawiskiem dość nietypowym, rzadko spotykanym ${ }^{11}$, sam zaś pomysł nadania poszczególnym jego częściom (ulicom, alejom, skwerom itp.) nazw pochodzących między innymi od imion/nazwisk postaci ważnych dla rozwoju ogrodu należy uznać za oryginalny i nowatorski.

Belgradzki Ogród Zoologiczny jest częścią kompleksu złożonego z twierdzy Kalemegdan oraz parku znajdującego się przy ujściu Sawy i Dunaju. Beo zoo vrt czy też Vrt dobre nade, bo tak również jest określany, został założony w 1936 roku dzięki staraniom ówczesnego burmistrza Vladimira Vlady Ilicia. W początkach swojej działalności zajmował obszar około 3,5 ha. Jego powierzchnia zmieniała się, z biegiem lat osiągając ponad 14 ha. Obecnie obejmuje 7 ha, na których żyje około 270 gatunków zwierząat ${ }^{12}$.

Warto zadać pytanie, dlaczego na terenie belgradzkiego zoo występują ulice, aleje, bulwary itp. Dlaczego dyrekcja ogrodu zdecydowała się na transpozycję nazewnictwa miejskiego do jego areału, jak również w jakich kategoriach należy interpretować ten zabieg?

7 P. Ewald, Ch. Klager, Namen von Zootieren. Zum Wesen und Gebrauch einer vernachlässigten Namenklasse, „Beiträge zur Namenforschung” 2007, z. 3, s. 325-345.

8 R. Łobodzińska, Nazwy zwierząt w nazwiskach polskich, ,Język a Kultura” 15. Opozycja homo-animal w języku i kulturze, red. A. Dąbrowska, Wrocław 2003, s. 129-134; J. Holeš, T. Typovský, Morfologicko-sémantická analýza českých př́imeni tvořených z názvư zvírat a uživaných na severní Moravě, „Naše řeč” 86, 2003, nr 3, s. 120-125; N. Vajs, Zoonimi u hrvatskim prezimenima, „Folia onomastica Croatica” 11, 2003, s. 223-238.

9 H. Uchwał, Apelatywy zwierzęce w przezwiskach szkolnych, „Balkan United”, http://balkanunited.wordpress.com/2012/06/27/apelatywy-zwierzece-w-przezwiskach-szkolnych/ [dostęp: 15.07.2018].

10 K. Handke, Nazewnictwo miejskie, [w:] Polskie nazwy własne. Encyklopedia, red. E. Rzetelska-Feleszko, Kraków 2005, s. 283.

${ }^{11} \mathrm{Z}$ podobnym zabiegiem spotkałam się jedynie w ogrodzie zoologicznym w Zagrzebiu.

12 http://www.beozoovrt.rs/istorijat/; http://www.rts.rs/page/magazine/sr/story/2523/nauka/2563557/vrt-dobre-nade.html [dostęp: 15.07.2018]. 
Jak wspomina Sonja Žakula, powstaniu belgradzkiego zoo, ale i innych ogrodów zoologicznych na terenie Serbii przyświecały - w mniejszym bądź większym stopniu - trzy idee: o mieście, o nauce i rozrywce oraz o turystyce ${ }^{13}$, realizowane zresztą w podstawowych funkcjach zoo. W kontekście rozpatrywanego zagadnienia najważniejsza wydaje się idea pierwsza — o mieście. $Z$ jednej strony ogród zoologiczny był fenomenem ówczesnej urbanistyki, z drugiej zaś był przepustką Serbii do „świata Zachodu”, Belgradowi natomiast umożliwiał awans do rangi „,pełnowartościowej” metropolii Królestwa Jugosławii ${ }^{14}$, a tym samym lokował go wśród innych wielkich światowych stolic z rozwiniętą urbanistyką, takich jak Londyn, Paryż czy Berlin, w których ogrody zoologiczne już funkcjonowały. Ponadto warto zauważyć, że wybór lokalizacji ogrodu również nie był przypadkowy. Miejsce to było siedzibą największego garnizonu wojskowego w kraju, a doprowadzona infrastruktura stanowiła doskonały grunt pod budowę ogrodu. Podjęto więc próbę stworzenia „miasta w mieście”, determinowaną przede wszystkim czynnikami politycznymi, kosmopolityzmem.

W rozważaniach należy wziąć pod uwagę aspekt kulturowy, symboliczy ogrodów zoologicznych, jak również podstawową relację człowiek-zwierzę. Istotna wydaje się tu druga ze wspomnianych idei, w myśl której ogród zoologiczny miał promować naukę, pełnić funkcje dydaktyczne, być instytucją kulturalną. $\mathrm{O}$ znaczeniu i potrzebie funkcjonowania ogrodów zoologicznych jako instytucji kulturalnych świadczy wypowiedź Dragutina Cankiego, którą cytuje w swojej monografii nieżyjący już dyrektor belgradzkiego zoo, piastujący to stanowisko 28 lat, Vuk Bojović:

Sva kulturna središta država po svijetu imadu zoološke vrtove. Zoološki vrt je kulturna institucija koja privlači sve narodne slojeve, od deteta do animalnog psihologa i umjetnika. [...] Zoološki vrt potreban je baš kao što su potrebne školske ustanove, muzeji i druge kulturne i naučne institucije. Zato zoološki vrt ne smije biti menažerija, da se posjetioci samo zabavljaju, već treba da služi u prvome redu za pouku kao uzgojno-naučna institucija ${ }^{15}$.

Odnosząc się do ogólnej relacji człowiek-zwierzę, relacji cechującej się asymetrią, determinowaną także nurtami filozoficznymi, należy podkreślić, że belgradzki ogród zoologiczny miał być instytucją uczącą miłości i szacunku do zwierząt, chroniącą je, pełniącą rolę — jak to określa S. Žakula — „simboličkog rajskog vrta bratstva i jedinstva među narodima sveta"16. Sam Aleksandar Krstić, jeden z dyrektorów i projektant zoo, wspominał:

13 S. B. Žakula, Zoološki vrtovi u Srbiji u antropološkoj perspektivi, doktorska disertacija, Beograd 2017, s. 218, https://fedorabg.bg.ac.rs/fedora/get/o:17239/bdef:Content/download [dostęp: 4.02.2019].

14 Ibidem.

15 Ibidem, s. 221. Cyt. za: V. Bojović, Beogradski zoološki vrt, Beograd: Beogradski zoološki vrt, 2010, s. 20, https://fedorabg.bg.ac.rs/fedora/get/o:17239/bdef:Content/download [dostęp: 15.07.2018].

16 S. B. Žakula, Zoološki vrtovi u Srbiji..., s. 278. 
Upoznati životinju znači — zavoleti je. Prema tome, ovaj Vrt treba da služi kao rasadnik ljubavi prema životinjama, što u krajnjoj liniji stvara najbolji preduslov za njihovu zaštitu i milosrdnije ophođenje. To su, uostalom, osobine na koje se kod kulturnih naroda mnogo polaže. Najzad, pored egzotičnih životinja, u Vrtu će naročito biti zastupljene sve domaće vrste životinjskog carstva. Na taj način će vršiti propagandu reprezentujući bogatstvo faune pojedinih naših krajeva... tako će Beogradski zoološki vrt imati značaja i sa gledišta turističko-kulturnog ${ }^{17}$.

Szczególnie trudnym okresem dla belgradzkiego zoo był czas wojny — chodzi zarówno o drugą wojnę światową, jak i rozpad Jugosławii. Zacne idee przyświęcające powstaniu i rozwojowi zoo uległy destrukcji. Po wojnie rozpoczęła się odbudowa ogrodu, walka o jego przetrwanie, samofinansowanie itp. W 1986 roku dyrektorem zoo został wspomniany V. Bojović — postać niezmiernie ważna dla ogrodu. Pod jego kierownictwem doszło do wielu zmian, przeprowadzono renowację, modernizację, pojawiły się nowe okazy zwierząt, przede wszystkim białe osobniki. Z materiałów źródłowych można wnioskować, że to właśnie V. Bojović był inicjatorem wprowadzenia nazewnictwa miejskiego do areału ogrodu zoologicznego. Mapa zoo z siatką ulic, bulwarów, placów, uwzględniająca tereny zielone, w pełni realizowała planistyczną koncepcję współczesnego miasta.

Nazwy własne obecne w przestrzeni miejskiej dają świadectwo historii danej społeczności, odzwierciedlają jej mentalność, kulturę, relacje społeczno-polityczne, upodobania, ukazują zmiany, które dokonały się w ciągu lat, stuleci. Być może właśnie próba przedstawienia historii ogrodu, chęć pokazania go w aspekcie kulturowym, podkreślenia tego, co dobre w kraju i mieście, co zasługuje na uwagę, stanowiło jedną z pobudek działań V. Bojovicia.

Wydaje się jednak, że nie należy w pełni utożsamiać klasycznego nazewnictwa miejskiego z prezentowanym zbiorem onimów zaświadczonym na terenie zoo. Dyferencje widoczne są $z$ jednej strony w specyfice pozyskanego materiału, $\mathrm{z}$ drugiej zaś w zdecydowanie uboższej bazie motywacyjnej stanowiącej podstawę nowych nominacji. Wśród nazw ulic, alei, targów, bulwarów, skwerów itp. znajdujących się na terenie belgradzkiego zoo nie znajdziemy nazw kierunkowych, nazw lokalizujących, charakteryzujących itp., typowych dla klasycznego nazewnictwa miejskiego. Jednak mimo tych różnic zauważalne są także analogie. Pozyskany materiał prezentuje nazwy o charakterze pamiątkowym/upamiętniającym. Ten typ motywacji należy obecnie do najbardziej produktywnych w nazewnictwie miejskim, wypiera inne, starsze, genetyczne typy motywacji ${ }^{18}$.

Warto tu przytoczyć słowa Kwiryny Handke:

Nazwy miejskie stanowią wierne odbicie różnych zjawisk społecznych. Najstarsza warstwa odzwierciedla sposób organizacji przestrzeni i życia mieszkańców miast, a zarazem

17 Ibidem. Cyt. za: V. Bojović, Beogradski..., s. 20.

18 Zob. np. K. Handke, Konstrukcja i destrukcja systemu nazewnictwa miejskiego w polskich miastach, [w:] Miasto w perspektywie onomastyki i historii, red. I. Sarnowska-Giefing, M. Graf, Poznań 2010, s. 362; В. Поломац, О савременим београдским ходонимима антропонимског порекла, „Acta onomastica” 54, 2013, s. 228-242. 
praktyczny stosunek ówczesnych kreatorów do nazw miejskich jako znaków deskrypcyjnych i funkcjonalnych. Nowsze warstwy nazw — zwłaszcza pamiątkowe - odzwierciedlają przede wszystkim symboliczne i pragmatyczne postawy i preferencje ich kreatorów ${ }^{19}$.

Za takiego kreatora uznać można V. Bojovicia, który w swoich wyborach i decyzjach z jednej strony kierował się historią działalności ogrodu, z drugiej zaś własnymi upodobaniami, preferencjami. Dla urbanonimów belgradzkiego ogrodu zoologicznego motywacje stanowiły imiona i nazwiska jego dyrektorów, osób, które wspierały zoo, osobowości znanych ze świata nauki, kultury, polityki, darczyńców, instytucji miejskich, również postaci, które miały znaczenie dla Małego Kalemegdanu. W jednym z wywiadów Bojović wybór nazw argumentował następująco: „Želeli smo da se odužimo onima koji su pomogli Vrtu kada smo bili prepušteni samo sebi. [...] Dobijali smo pomoć u vidu asfaltiranja i osvetljenja ulica, kupovine životinja i donacija. Neki su, pak, kroz stvaralaštvo predstavili »zoo vrt«"20.

Ekscerpcja materiału odbyła się dwukrotnie — w 2011 oraz 2018 roku. Podczas przeprowadzonych kwerend zebrano 36 jednostek onimicznych. Bazę materiałową poddano analizie semantycznej i formalnej.

35 z 36 zaświadczonych nazw to kreacje powstałe w procesie transonimizacji. W obrębie zebranego materiału można wyróżnić dwie podstawowe grupy: nazwy utworzone od innych nazw własnych oraz nazwy utworzone od apelatywów. W pierwszej grupie można wprowadzić podział na cztery podgrupy ze względu na rodzaj bazy nazwotwórczej: bionimiczną, toponimiczną, chrematonimiczną, mieszaną - chrematonimiczno-antroponimiczną. Najliczniej zostały zaświadczone nazwy utworzone od bionimów, z uwzględnieniem następujących kategorii: imię, nazwisko, przydomek, imię z określeniem poimiennym, zdecydowanie rzadsze były inspiracje chrematonimiczne, w materiale odnotowano tylko jedną nazwę z podstawą toponimiczną, jedną nazwę mieszaną oraz jedną nazwę z podstawą apelatywną.

Szczegółowa klasyfikacja semantyczna przedstawia się następująco:

I. Nazwy utworzone od innych nazw własnych

1. Motywowane bionimami:

1. 1. z podstawą antroponimiczną:

1.1.1. w formie imienia i nazwiska:

1.1.1.1. dyrektorów ogrodu zoologicznego oraz jego założyciela:

PROSPEKT VLADE ILIĆA - burmistrz Belgradu i inicjator założenia ogrodu zoologicznego; ULICA ALEKSANDRA KRSTIĆA — architekt i dyrektor zoo; AVENIJA MIODRAGA SAVKOVIĆA — dyrektor zoo w latach 1941-1944; AVENIJA ANTE TADIĆA - dyrektor zoo w latach 1945-1948; AVENIJA MILORADA MEDENICE - dyrektor zoo w latach 1952-1981; FORUM VUKA BOJOVIĆA — dyrektor zoo w latach 1986-2014;

19 K. Handke, Konstrukcja i destrukcja systemu..., s. 362.

$20 \mathrm{http} / /$ www.novosti.rs/vesti/beograd.74.html:213124-Paunovi-u-Kustinoj-ulici [dostęp: 15.07.2018]. 
1.1.1.2. postaci związanych z życiem naukowym, kulturalnym, politycznym, osób wspierających zoo, ważnych dla Małego Kalemegdanu, również postaci medialnych niezwiązanych z Serbią:

AVENIJA MILUTINA MILANKOVIĆA — serbski naukowiec; AVENIJA EMIRA KUSTURICE - jugosłowiański reżyser filmowy; ULICA VELJKA BIKIĆA — założyciel pierwszej prywatnej pracowni animacji w byłej Jugosławii; TRG ZORANA SIMJANOVIĆA — serbski kompozytor; TRG NIKA ANIĆIĆA darczyńca białych lwów i gepardów; ULICA TOME JEREMIĆA - serbski naukowiec; ULICA DOCENTA DUŠANA STANOJEVIĆA - serbski naukowiec, ginekolog, pomagał w leczeniu i przyjściu na świat wielu zwierząt w zoo; STEPENIŠTE IGORA MARIĆA - serbski architekt, który zaprojektował kilka większych obiektów w zoo; ULICA ALEKSANDRA BAKOĆEVIĆA — działacz społeczno-polityczny; TERMINAL SLOBODANA STRIČEVIĆA - serbski pilot; BULEVAR DUŠANA KOVAČEVIĆA - serbski dramaturg; AVENIJA DANIJELA SVAROVSKOG TREĆEG — założyciel przedsiębiorstwa Svarovski; AVENIJA NOVAKA ĐOKOVIĆA — serbski tenisista; ULICA SAVE PINTARA — jeden z założycieli i prezes Towarzystwa Ochrony i Hodowli Ptaków „Slavuj”; $D V E$ RI JOCE PEJČIĆA — chodzi albo o doktora Jovana Pejčicia, znanego judokę $e^{21}$ i założyciela stowarzyszenia Svetska tamburaška asocijacija, albo o serbskiego krytyka i eseistę;

1.1.2. w formie imienia:

ULICA NEBOJŠINA — od imienia Nebojšy Čovicia, burmistrza Belgradu, polityka, przedsiębiorcy, z którym sympatyzował V. Bojović; ULICA ZLATANOVA — od imienia Zlatana Peručicia, przewodniczącego Rady Wykonawczej Miasta Belgradu; JOVINO SOKAČE — od imienia Jovana Jovanovicia Zmaja, serbskiego pisarza okresu romantyzmu, cenionego przez zmarłego dyrektora zoo V. Bojovicia (sokače 'uliczka' z j. tureckiego); BORIN ĆORSOKAK — od imienia serbskiego muzyka Bory Čorby (właściwie Borislav Đorđević), wokalisty grupy Riblja čorba (ćorsokak 'ślepa uliczka, zaułek'); MONIKIN TESNAC — aluzja do seksafery z udziałem Moniki Levinski i prezydenta Clintona (tesnac 'cieśnina');

1.1.3. w formie imienia, nazwiska i przydomka:

PROSPEKT DRAGANA MARKOVIĆA PALME - serbski polityk, przedsiębiorca, twórca stacji telewizyjnej Palma plus, od której otrzymał przydomek „Palma”;

1.1.4. $\mathrm{w}$ formie imienia i nazwiska uzupełnionego imieniem $\mathrm{z}$ określeniem poimiennym:

SKVER MILUTINA VASILIJEVIĆA MILUTINA OD ROSFRAJA - chociaż jest oczywiste, że nazwa ta motywowana jest imieniem i nazwiskiem wraz $\mathrm{z}$ uzupełnieniem $\mathrm{w}$ formie imienia $\mathrm{z}$ określeniem poimiennym, niestety nie udało się ustalić, kim dokładnie był Milutin Vasilijević. Człon poimienny w formie

21 Za taką interpretacją przemawia to, że V. Bojović był między innymi wiceprzewodniczącym Jugosłowiańskiej Konfederacji Judo. 
atrybutu niekongruentnego najprawdopodobniej pochodzi od niemieckiego przymiotnika rostfrei 'nierdzewny', być może wskazuje na powiązanie z firmą Rostfrei-Stahl Geisweid GmbH zajmującą się produkcją stali nierdzewnej.

2. Toponimy:

ULICA KIRGIZISKA (Kirgizijska) - prawdopodobnie chodzi o nazwę Republiki Kirgiskiej, która stała się celem jednej z podróży V. Bojovicia ${ }^{22}$. Warto wspomnieć, że przy tej ulicy można spotkać orła przedniego, który zamieszkuje między innymi Kirgistan, Azję. W ramach ciekawostki można dodać, że 1 kwietnia 2018 roku w belgradzkim zoo wykluł się orzeł dwugłowy, ostatnie tego typu zjawisko zaobserwowano w 1927 roku właśnie w Kirgistanie.

3. Motywowane chrematonimami:

3.1. w formie akcjonimu:

STAZA BEOGRADSKOG MARATONA — od belgradzkiego wydarzenia sportowego Maraton, którego trasa przebiega koło ogrodu zoologicznego;

3.2. w formie instytucjonimu:

AVENIJA TELEKOM SRBIJA — od nazwy serbskiej firmy telekomunikacyjnej z siedzibą w Belgradzie; AVENIJA CEPTER — od firmy Zepter produkującej naczynia, która sprezentowała ogrodowi dwie żyrafy; AVENIJA BEOGRAD PUTA — od belgradzkiego przedsiębiorstwa Beograd put specjalizującego się w projektowaniu, budowie oraz konserwacji dróg i ulic; ULICA BEOGRADSKIH ELEKTRANA — od przedsiębiorstwa Beogradske elektrane zajmującego się produkcją i dystrybucją energii cieplnej.

4. Nazwy mieszane (chrematonimiczno-antroponimiczne):

TRG K.K. PARTIZAN DULE VUJOŠEVIĆ — od nazwy klubu koszykarskiego (K.K.) Partizan oraz imienia (w formie hipokorystycznej) i nazwiska trenera klubu Dušana Vujoševicia, z którym sympatyzował V. Bojović.

II. Nazwy utworzone od apelatywów:

SKVER MAKEDONSKIH KONOBARA — od makedonski konobar, nazwa nawiązuje do wydarzenia z 1999 roku, kiedy to grupa kelnerów ze skopijskiej tawerny pobiła żołnierzy NATO.

Motywacje zaprezentowanych urbanonimów w większości są czytelne. Funkcjonują jednak i takie nominacje, przy których określenie właściwego źródła motywacji może przysporzyć trudności, przede wszystkim w wypadku nazw powstałych od imion. Ulica Nebojšina, Zlatanova itp. — możemy się jedynie domyślać, że podstawą tych kreacji onimicznych były popularne południowosłowiańskie imiona, natomiast problematyczne może być zidentyfikowanie ich właściwych nosicieli. Jak wynika z przeanalizowanego materiału, zdecydowana większość nazw to kreacje deantroponimiczne. Ten typ nazewnictwa reprezentuje nowszą warstwę nazewniczą, w dużej mierze wpisuje się także w konwencję modelu nazewniczego belgradzkich ulic. Jak wynika z badań przeprowadzonych przez Vladimira Polo-

22 Dopuszczalną motywację mógłby stanowić również etnonim Kirgizi — od nazwy narodu turecko-mongolskiego Kirgizi. 
maca, prawie $60 \%$ belgradzkich hodonimów ma antroponimiczną bazę motywacyjną, o charakterze pamiątkowym, w której najproduktywniejsze są motywacje w postaci imion i/lub nazwisk członków przedwojennego ruchu komunistycznego, członków ruchu partyzanckiego podczas drugiej wojny światowej, jak również ofiar tejże wojny, następnie imion i/lub nazwisk znanych osób z serbskiej i światowej kultury (pisarzy, naukowców, malarzy, filmowców itp.), postaci znanych z serbskiej historii XIX i XX wieku, a także doby średniowiecza, osób ważnych dla historii Belgradu ${ }^{23}$. Onimy zaświadczone w belgradzkim zoo motywowane są imionami i nazwiskami postaci zasłużonych dla ogrodu — przede wszystkim jego dyrektorów, ludzi stojących na jego czele, kierujących nim. Ulic doczekali się również niektórzy urzędnicy, $\mathrm{z}$ których inicjatywy miasto pomagało w realizacji projektów na terenie zoo (np. Nebojša Čović, Zlatan Peručić). Na tabliczkach pojawiają się także imiona i nazwiska osób związanych z jugosłowiańskim/ serbskim życiem kulturalnym i naukowym, również darczyńców. Niektóre z tych postaci miały bezpośredni wpływ na funkcjonowanie ogrodu, na polepszenie jego sytuacji materialnej, na jego zagospodarowanie, przebudowę, powiększenie i urozmaicenie ekspozycji, inne zaś zawdzięczają ulice swojemu całokształtowi twórczemu, zasługom dla kultury, miasta, kraju. Wybór nazw z planu chrematonimicznego również nie był przypadkowy. Pomoc firm (Cepter, Beograd put, Telekom Srbija, Beogradske elektrane) w dostarczaniu energii, ciepła, oświetlenia, położenia/renowacji powierzchni asfaltowej, pożywienia dla zwierząt, monitorowaniu sępów płowych za pomocą nadajników satelitarnych była dla ogrodu niezmiernie ważna. Nazwą budzącą zbieżne odczucia, z dozą ironii, może nawet niepasującą do pozostałych, jest Monikin tesnac, którą zostało obdarzone wąskie przejście w zoo. W konwencję ogrodu zoologicznego niekoniecznie wpisuje się także nominacja Skver makedonskih konobara. Jak pisze S. Žakula, między innymi w wyniku wprowadzenia nazewnictwa ulic na teren ogrodu zoologicznego „vrt koji je nekada igrao ulogu simboličkog rajskog vrta bratstva i jedinstva među narodima sveta je izgubio značenje i ideološku potporu države, a na upražnjeno mesto je stupio ne-toliko-banalni nacionalizam i cirkuzantsko politikanstvo $\mathrm{Vu}$ ka Bojovića" ${ }^{24}$. Jednak z perspektywy promocji kraju, miasta, historii zoo, upamiętnienia postaci dla niego kluczowych, ważnych dla kultury, transpozycję nazewnictwa miejskiego do areału ogrodu zoologicznego można odbierać również w kategoriach pozytywnych.

Sam przeprowadzony zabieg można interpretować jako przejaw patriotyzmu, z lekkim zabarwieniem nacjonalistycznym. Nie sposób odmówić V. Bojoviciowi wielkich zasług dla ogrodu. $Z$ wykształcenia rzeźbiarz okazał się człowiekiem o wielkim sercu i empatii dla zwierząt, współpracującym z rożnymi instytucjami zagranicznymi. Jednakże jego uczestnictwo w dyskursie politycznym nie zawsze było odbierane przychylnie. Postawa Bojovicia przejawiała się w sprzeciwie

23 В. Поломац, О савременим београдским ходонимима..., s. 237-238.

24 S. B. Žakula, Zoološki vrtovi u Srbiji..., s. 278-279. 
wobec przemocy, a przede wszystkim bombardowania Jugosławii przez NATO. Prawdopodobnie to właśnie wydarzenia polityczne wyzwoliły w nim wachlarz emocji, które uwidoczniły się między innymi w stosowaniu ironii, co zresztą potwierdza obecność wspomnianych nazw. Innym tego przykładem może być nazwanie dwóch pytonów w okresie bombardowania NATO imionami sekretarzy stanu: Warrena Christophera i Madeleine Albright. Oczywiście tego typu działania, zachowania mogą wzbudzać odmienne odczucia, być wykładnikiem innej postawy wartościująco-oceniającej, wśród mieszkańców Belgradu, Serbii, byłej Jugosławii, inne zaś wśród obcokrajowców odwiedzających zoo, którzy, znając cyrylicę, są w stanie zdekodować informacje zamieszczone na tabliczkach. Turyści zwiedzający ogród wcale nie muszą być zaznajomieni z orientacją polityczną dyrekcji ogrodu. Wraz z rozwojem kultury masowej wzrosła również funkcja reklamowa różnych instytucji. Nacisk między innymi na samofinansowanie ogrodu wyzwolił całą serię działań, czynności marketingowych, służących jego promocji, zarówno w kraju, jak i za granicą.

Pod względem formalnym prezentowane urbanonimy to w większości struktury dwu- lub trzyczłonowe, w których jeden z elementów jest członem utożsamiającym (najczęściej jest to element A), drugi i trzeci zaś członami odróżniającymi (B i C $)^{25}$. Człony utożsamiające występują w formie rzeczowników pospolitych, wśród których można wyróżnić następujące: avenija (10), ulica (10), trg (3), skver (2), prospekt (2), bulevar (1), staza (1), sokače (1), dveri (1), tesnac (1), forum (1), ćorsokak (1), stepenište (1), terminal (1). Do nielicznych należą nazwy wieloczłonowe (powyżej trzech elementów), na przykład TRG K.K. PARTIZAN DULE VUJOŠEVIĆ.

W zebranym materiale pojawiają się zarówno derywaty semantyczne, jak i nazwy z modyfikacją słowotwórczą. $\mathrm{W}$ postaci przeniesień, czyli form mianownikowych, występują tylko trzy nazwy - dwie z podstawą chrematonimiczną: AVENIJA TELEKOM SRBIJA, AVENIJA CEPTER, trzecia zaś mieszana, chrematonimiczno-antroponimiczna: K.K. PARTIZAN DULE ${ }^{26}$ VUJOŠEVIĆ. Najliczniejszą grupą są formy dopełniaczowe, prezentowane przez kilka modeli. Modele antroponimiczne realizowane są przez następujące zestawienia: a) imię + nazwisko w dopełniaczu liczby pojedynczej (20), na przykład AVENIJA MIO$D R A G A S A V K O V I C ́ A$, b) imię + nazwisko + liczebnik porządkowy w dopełniaczu liczby pojedynczej (1), na przykład AVENIJA DANIJELA SVAROVSKOG TREĆEG , c) tytuł naukowy + imię + nazwisko w dopełniaczu liczby pojedynczej (1), na przykład ULICA DOCENTA DUŠANA STANOJEVIĆA, d) imię + nazwisko + imię z określeniem poimiennym $\mathrm{w}$ dopełniaczu liczby pojedynczej (1): SKVER MILUTINA VASILIJEVIĆA MILUTINA OD ROSFRAJA. W odniesieniu do schematów chrematonimicznych można zaproponować zestawienia:

25 E. Rzetelska-Feleszko, Nazwy miejskie (urbanonimia/urbonimia), [w:] Stowiańska onomastyka. Encyklopedia, t. 2, red. E. Rzetelska-Feleszko, A. Cieślikowa, współpraca J. Duma, Warszawa-Kraków 2003, s. 296.

${ }^{26}$ Imię Dule (od Dušan) podane jest w formie hipokorystycznej. 
a) chrematonim (przymiotnik + rzeczownik) w dopełniaczu liczby pojedynczej (1), na przykład STAZA BEOGRADSKOG MARATONA, b) chrematonim (przymiotnik + rzeczownik) w dopełniaczu liczby mnogiej (1), na przykład ULICA BEOGRADSKIH ELEKTRANA, oraz c) chrematonim (rzeczownik w mianowniku liczby pojedynczej + rzeczownik w dopełniaczu liczby pojedynczej) (1), na przykład AVENIJA BEOGRAD PUTA. Z podstawą apelatywną zaświadczona została jedna nazwa - SKVER MAKEDONSKIH KONOBARA, której człon odróżniający tworzy zestawienie przymiotnik + rzeczownik w dopełniaczu liczby mnogiej. Oprócz form dopełniaczowych w zebranym materiale odnotowano struktury z charakterystycznymi dla nazewnictwa miejskiego formantami przymiotnikowymi (6): -in, -ov, -sk, na przykład MONIKIN TESNAC, JOVINO SOKAČE, ULICA NEBOJŠINA, ULICA ZLATANOVA, ULICA KIRGIZISKA. Zaprezentowane modele, szczególnie antroponimiczne, pokrywają się ze strukturami wyodrębnionymi przez V. Polomaca. Za najproduktywniejsze formy belgradzkich hodonimów uznał on także formy dopełniaczowe.

Warto zasygnalizować, że na obszarze belgradzkiego zoo, podobnie jak w przestrzeni miejskiej, dostrzec można antynomię centrum — peryferie. W najważniejszej części ogrodu znajdują się ulice inspirowane imionami i nazwiskami jego dyrektorów, postaci najbardziej znaczących dla jego prosperowania, kolejne zaś elementy topografii, bliżej czy dalej usytuowane, otrzymały nazwy po osobach i instytucjach, które okazały pomoc ogrodowi.

Zebrany materiał należy uznać za interesujący. Spacer ścieżkami belgradzkiego zoo to nie tylko przechadzka wśród zwierząt, ale przede wszystkim podróż przez historię ogrodu, historię, kulturę miasta i kraju. Transpozycja modelu nazewnictwa miejskiego do przestrzeni ogrodu zoologicznego, którego intencją było uhonorowanie osób ważnych dla ogrodu i postaci znanych z życia naukowego, kulturalnego, odzwierciedla najnowsze tendencje w nazewnictwie miejskim.

\section{Bibliografia}

Ewald P., Klager Ch., Namen von Zootieren. Zum Wesen und Gebrauch einer vernachlässigten Namenklasse, „Beiträge zur Namenforschung” 2007, z. 3.

Głowacki J., Imiona własne zwierząt w Ogrodzie Fauny Polskiej w Bydgoszczy, „Język Polski” 77, 1992.

Grković M., Gradski nazivi (urbanonimi), [w:] Słowiańska onomastyka. Encyklopedia, t. 2, red. E. Rzetelska-Feleszko, A. Cieślikowa, współpraca J. Duma, Warszawa-Kraków 2003.

Habel A., Mroczkowski S., Cele i zadania ogrodów zoologicznych, „Journal of Education, Health and Sport" 5, 2015, z. 8.

Handke K., Konstrukcja i destrukcja systemu nazewnictwa miejskiego w polskich miastach, [w:] Miasto w perspektywie onomastyki i historii, red. I. Sarnowska-Giefing, M. Graf, Poznań 2010.

Handke K., Nazewnictwo miejskie, [w:] Polskie nazwy własne. Encyklopedia, red. E. Rzetelska-Feleszko, Kraków 2005.

Holeš J., Typovský T., Morfologicko-sémantická analýza českých př́jmeni tvořených z názvů zvírat a uživaných na severni Moravě, „Naše řeč” 86, 2003, nr 3. 
Jakus-Borkowa E., Nazwy własne zwierząt ogrodów zoologicznych w Opolu i we Wrocławiu, [w:] Systemy zoonimiczne w językach stowiańskich, red. S. Warchoł, Lublin 1996.

Kołodziej A., Nazewnictwo zwierząt ogrodów zoologicznych, [w:] Propria a apelativa - aktuálni otázky. Proper Names and Common Nouns - Current Issues, red. L. Janovec, Praha 2019.

Łobodzińska R., Nazwy zwierząt w nazwiskach polskich, „Język a Kultura” 15. Opozycja homoanimal w języku i kulturze, red. A. Dąbrowska, Wrocław 2003.

Polomac V., O savremenim beogradskim hodonimima antroponimskog porekla, „Acta onomastica" 54, 2013.

Rzetelska-Feleszko E., Nazwy miejskie (urbanonimia/urbonimia), [w:] Stowiańska onomastyka. Encyklopedia, t. 2, red. E. Rzetelska-Feleszko, A. Cieślikowa, współpraca J. Duma, Warszawa-Kraków 2003.

Tomaszewska S., Nazwy własne zwierząt tódzkiego Ogrodu Zoologicznego, „Rozprawy Komisji Językowej ŁTN" 25, 1979.

Uchwał H., Apelatywy zwierzęce w przezwiskach szkolnych, „Balkan United”, http://balkanunited.wordpress.com/2012/06/27/apelatywy-zwierzece-w-przezwiskach-szkolnych/ [dostęp: 15.07.2018].

Vajs N., Zoonimi u hrvatskim prezimenima, „Folia onomastica Croatica” 11, 2003.

Žakula S. B., Zoološki vrtovi u Srbiji u antropološkoj perspektivi, doktorska disertacija, Beograd 2017, https://fedorabg.bg.ac.rs/fedora/get/o:17239/bdef:Content/download [dostęp: 15.07.2018].

Ustawa z dnia 16 kwietnia 2004 roku o ochronie przyrody, http://prawo.sejm.gov.pl/isap.nsf/download.xsp/WDU20040920880/O/D20040880.pdf [dostęp: 15.07.2018].

\section{Źródła internetowe}

http://arhiva.glas-javnosti.rs/arhiva/2004/09/27/srpski/BG04092602.shtml [dostęp: 15.07.2018]. http://avikultura.forumsr.net/t1418-drustvo-za-zastitu-i-odgoj-ptica-slavuj-beograd [dostęp: 15.07.2018]. https://www.blic.rs/vesti/beograd/cudo-u-beogradskom-zoo-vrtu-izlegao-se-dvoglavi-orao/7nq95nf [dostęp: 4.02.2019].

http://www.novosti.rs/vesti/beograd.74.html:213124-Paunovi-u-Kustinoj-ulici [dostęp: 15.07.2018]. http://www.novosti.rs/vesti/naslovna/reportaze/aktuelno.293.html:527919-Veronauku-i-ucenike-zamenila-za-zivotinje [dostęp: 15.07.2018].

https://www.vreme.com/cms/view.php?id=510391 [dostęp: 15.07.2018].

\section{Onomastic walk through the streets of the Belgrad zoo}

\section{Summary}

This article discusses urban names found in the zoo in Belgrad. The article is an attempt to find out why the managers of the zoo decided to transpose urban names into the area of the zoo and in what categories we can perceive this choice.

The body of material, including 36 onymic units, was subject to semantic and formal analysis. The material includes commemorative names referring i.a. to the first names and surnames of the zoo directors, figures connected with science and culture, or the names of institutions supporting the zoo. The vast majority of them are formal language structures, especially genitive forms.

The presented semantic and formal models follow the convention of the contemporary nomenclature of streets in Belgrad. The very transposition must be regarded as innovative, deter- 
mined on the one hand by the development of mass culture and on the other hand by political reasons, which can be perceived in the category of patriotism with a slightly nationalistic tinge.

Keywords: urban names, zoo, Belgrad

\section{Onomastička šetnja stazama Beogradskog zoološkog vrta}

Rezime

Članak se bavi gradskim nazivima koji su zabeleženi na terenu Beogradskog zoološkog vrta. U članku se probalo odgovoriti na pitanja zbog čega se direkcija zoološkog vrta odlučila na transpoziciju gradskih naziva u arelu zoološkog vrta kao i kojim kategorijama se to može analizirati.

Ispitivani korpus se sastoji od 36 onimične jedinice, analizirane semantički i formalno. Sakupljeni materijal predstavlja nazive koji su svojevrsna vrsta sećanja, a čija se motivacija, između ostalog, odnosi na imena i prezimena direktora zoološkog vrta, osoba povezanih sa naukom, kulturom, kao i nazivi institucija koje podržavaju zoološki vrt. Uglavnom su to strukture sa formalnojezičkom kreacijom, usred kojih dominiraju forme genitiva.

Predstavljeni semantički i formalni modeli uklapaju se u konvenciju savremenih naziva beogradskih ulica. Samu transpoziciju bi trebalo smatrati za inovatorsku koja je sa jedne strane determinisana razvojem masovne kulture, a sa druge političkim povodima koji se mogu analizirati u patriotskim kategorijama sa izvesnom dozom nacionalizma.

Ključne reči: gradski nazivi, zoološki vrt, Beograd 